\title{
Queer Liveability: Inclusive Church-Scenes
}

\author{
Author Copy
}

\section{Karen Cuthbert and Yvette Taylor}

\begin{abstract}
This paper explores queer religious youths' engagement with the Metropolitan Community Church (MCC) - a church founded as a space of worship for LGBT Christians. Interested in sources of wellbeing in queer people's lives, we show how MCC provided young religious queer people with a sense of home, family, and a phenomenological experience of 'fit' and 'ease'. We connect to literature on the subjectivisation of religion and suggest that MCC is a significant actor in this process, with spatial and liturgical practices which encourage the development of one's own spiritual journey. However, we also temper these claims by showing how 'tradition' was still valued by many participants, evidenced in their continued affiliation with other (often non-inclusive) churches. We argue that this complicates arguments regarding 'inclusivity' as these 'non-inclusive' churches could also provide spaces of succour and support. Finally, we also consider MCC's relationship with queerness/LGBT: participants differed in whether or not they saw MCC as part of or apart from the 'scene', complicating questions raised about assimilation vs separatism, with the relative weight of 'LGBT' and 'Christian'.
\end{abstract}

\section{Keywords:}

Metropolitan Community Church (MCC); Christian; Queer; Religion; Youth

\section{Introduction}

This article explores UK-based queer religious young people's experiences with Metropolitan Community Churches (hereafter MCC) - a church founded originally as a space of worship for gay Christians in 1960s Los Angeles. The data from this article comes from a larger project which explored various facets of queer religious young people's lives, such as their experiences of secondary and higher education (Author; Author), their engagement with religious music (Author), their views on gender and the church (Author), their use of social media (Author), and their construction of vocational and familial futures (Author).

Religion and sexuality constitute a flashpoint in current Western socio-political discourse, with religion and non-heterosexualities frequently characterised as mutually exclusive (Shipley, 2014). Whilst there is a long tradition of queer theology (e.g. Althaus-Reid, 2000), within the social sciences research on LGBT and queer lives have historically paid little 
attention to religion, except as a source of oppression (O'Brien, 2014). However, Rodriguez (2009: 8) writes of a paradigm shift that is underway, where queer people are recognised as 'spiritual and religious beings in their own right, rather than merely sexual beings needing to be compared and contrasted with religious others'. Much of this research has been concerned with how individuals integrate these seemingly dissonant parts of their identities using various strategies of accommodation and compartmentalization (e.g. Ganzevoort et al., 2011). But research has also been conducted on religious queer people's participation in in/formal religious and faith practices (e.g. Gross and Yip, 2010) and experiences of religious-sexual inclusions and exclusions across the lifecourse (Davie and Vincent, 1998; Westwood, 2017). In turn, 'youth' and 'religion' (particularly Christianity) are also often constructed as incompatible categories, with a tendency to interpellate young people as bearers of an inexorable secularization. But again, research - problematizing a strict institutional conception of religion - is showing the significance of religious faith, belonging, and connection in the lives of many young people (e.g. Collins-Mayo and Dandelion, 2010; Madge et al., 2014).

What it is like to be young, queer and religious, however, remains under-explored, since to some extent these are still categories of belonging that are characterised in opposition to each other (Author). Extant research on this intersection has tended to focus on how queer youth 'survive' religious institutions such as Catholic schools (e.g. Callaghan, 2016), reflective of a trend observed in much current UK governmental policy and academic research in which queer young people are (implicitly or explicitly) positioned as 'at risk' from a range of physical, psychological, and social harms (McDermott and Roen, 2016). A number of authors have argued that this narrative of risk might cause harm in and of itself, including the danger of pathologising non-heterosexuality as a suicide risk factor (Cover, 2012: 3) and the continued construction of queer youth as Other (Rasmussen, 2006).

This study therefore takes a different approach in looking at a source of support and affirmation in the lives of some queer religious youth: the space of the 'inclusive church', specifically the institutional setting of MCC. Struggles and vulnerabilities are part of this story (e.g. homophobic rejection from family and from other churches), as well as ambiguities (e.g. frustrations with MCC) but it is our hope that not only do we hold open discursive space in which queer youth can also be religious, but we also contribute to emerging literature on queer wellbeing and liveability: what it is like to thrive rather than simply survive.

We begin by giving an overview of the MCC and of previous sociological research in this area. We then provide information on how the data for this article was collected and analysed, before turning to our findings, which are organised under five headings: 'Feeling Included: Metaphors of Home and family'; 'MCC and the Subjectivisation of Religion'; 'Feeling Tradition'; 'Religious-Sexual Exclusions'. The paper not only highlights issues at the intersection of queer, religion and youth, but also represents one of the first studies on MCC in the UK.

\section{Metropolitan Community Church}


Christianity is an enormously diverse religion, and Christian denominations can hold a variety of perspectives on homosexuality ranging from tolerance to outright condemnation, but generally speaking, there has been little space (at least officially) for LGBT persons within Christianity (Gross and Yip, 2010: 41). The original Metropolitan Community Church was founded in Los Angeles in 1968 by Troy Perry, a former Pentecostal pastor who had been defrocked in the early 1960s due to his homosexuality. Perry's founding of MCC was intended to open up a gay-affirming and inclusive space of worship for same-sex attracted Christians (MCC, 2013).

Over the next four decades MCC would expand to include 242 ministries in 40 different nations worldwide, including 16 in the UK (MCC, 2012). MCC describes itself as moving in the 'mainstream of Christianity' in that it adheres to key tenets of the Christian faith (Wilcox, 2003: 19) but it is also a profoundly ecumenical organisation affording individual congregations and pastors considerable autonomy with regards sacraments, rites, and styles of worship. MCC congregants rarely convert to Christianity through MCC but rather come from a wide variety of Christian backgrounds (Kane, 2012: 139), and so MCC attends to this diversity by ranging from 'high church' styles (Catholicism and Anglicanism), to evangelical and charismatic forms of worship, to even New Age Goddess-based spirituality (Wilcox, 2003: 19).

MCC adopts a historiographical and critical approach to biblical scholarship (Lukenbill, 1998: 444) which facilitates the re-interpretation of biblical passages that would otherwise seem to prohibit homosexuality. For example, the story of Sodom and Gommorah in the Old Testament is read not as a condemnation of homosexual activities, but rather a condemnation of rape, pride, and of the inhospitality that the men of Sodom showed towards the visitors (MCC, 2016). From early on, the MCC has also adopted a policy of inclusive language in which God is no longer conceived of in exclusively male terms (MCC, 2015: 8). Indeed, the MCC has always been clear that it is not just a 'gay church', but is rather a 'safe space with life affirming messages about God's creativity, love, and Spirit...grounded in God's radically inclusive love for all people' (MCC, 2015: 9-10).

\section{Research on MCC}

Research on MCC has been sporadic at best. Kane (2013: 138) remarks that there has been a relative 'inattention' paid to MCC by sociologists of religion, as well as by sociologists of sexuality. Kane suggests that this might be due to the neglect of denominations and congregations more broadly within the sociology of religion on the one hand and on the other, the long-standing queer and feminist distrust of Christianity, particular in its organisational and institutional forms (Aune, 2015; Aune and Stevenson, 2017). However, there have been some pockets of interest, and we suggest that this research can be seen as falling into two broad (overlapping) categories: the ethnographic, and the historical/documentary. Ethnographic studies of various American MCC congregations began in the 1970s, shortly after MCC's inception. Early work such as that by Enroth and Jamison (1974) displayed scepticism with regards the religious element of MCC, arguing that MCC San Francisco represented just another cruising site for gay men. Later ethnographies focused on how MCC congregants integrated their religion with their sexuality, given Christianity's assumed 
incompatibility with homosexuality, and how MCC provided an important space for 'identity work' (Rodriguez and Ouelette, 2000); the role MCC played in the gentrification of a particular Washington DC neighbourhood (Paris and Anderson, 2001); and an in-depth exploration and comparison of two Californian MCC congregations, covering the life histories of individual congregants, to how ritual and myth are used, to the tensions between conservative and radical impulses in the MCC (Wilcox, 2003). Recently, ethnographic work has appeared which is critical of the assimilatory and homonormative tendencies of MCC (McQueeney, 2009), as well as how ostensibly inclusive discourse in MCC can often be exclusionary, reproducing hierarchies of respectability and morality, as well as sexist and patriarchal views (Sumerau, 2012a, b; Sumerau et al., 2015; Sumerau, 2017).

Historical and documentary research has been concerned with the formation and expansion of MCC and the social, cultural and political factors affecting this (Warner, 1995; White, 2008; Kane, 2013), its theological underpinnings (Warner, 1995) and its 'corporate culture' (Lukenbill, 1998). Attention has also been paid to MCC's potential as a 'political actor' in LGBT and queer advocacy, given its 'putatively apolitical identity as a church, with the legitimating power of churchness' (Howe, 2007: 102).

The MCC is, however, not the only LGBT or LGBT-affirming denomination or religious group (see White (2008) for a historical overview of LGBT religious organising). Research has also been conducted on the Catholic LGBT organisation Dignity (Loseke and Cavendish, 2001; Radojcic, 2016), the United Church of Christ's LGBT congregation Cathedral of Hope in Dallas (Johnston and Jenkins, 2004) and, moving away from Christianity, the Congregation Beth Simhat Torah, a queer Jewish synagogue in New York (Shokeid, 1995). However, all of the above research has been in the US context. Despite the fact that England, Scotland and Wales have more MCC ministries than any other country outside the US (MCC 2012), there has been little research based on MCC, or on how people engage with MCC, in the UK. An exception is two previous publications which touched upon MCC when exploring how queer religious youth engaged with congregational music (Author), and how young lesbians found 'space' in Church (Author). In the first article, one participant reflects on how the music played in her MCC congregation has challenged her view of what music is 'appropriate' for Church (i.e. more modern, use of instruments etc.) but also stresses the importance of confining music to a time in the service when it is 'appropriate'. In the second, two participants commented on how the leadership of MCC congregations they attended were comprised mostly of women, although they had contrasting views on the desirability of this. However, these articles were about particular substantive areas (music, space for women in church) rather than MCC itself. This article builds upon these initial explorations by specifically focusing on how young people in the UK engaged with the MCC, representing the first research foregrounding both young people and the UK context.

\section{Methods}

The data in this article comes from the larger ESRC-funded project 'ANON', in which 38 queer and religiously identified young people in Manchester, London, and Newcastle were interviewed about various aspects of their identities and experiences between 2011-2012. We use the term 'queer' in this article as an umbrella term to encompass the diverse subjectivities of participants, some of which sat outside the 'LGBT' paradigm. We also describe participants throughout as 'religious' rather than exclusively Christian, in recognition of how 
some participants' preferred to identify with their denominational background rather than with 'Christian' per se, whilst others had identities that exceeded 'Christian' (such as those who were Buddhist or Pagan Christians). The project defined 'youth' as up to age 35 in order to reflect the widening parameters of 'youth', particularly in a context of economic and social precarity where adult children often do not leave their parents' homes until their 30s (ONS, 2014). However, the majority of participants (63\%) were aged under 25.

17 participants out of 38 attended or were affiliated with MCC in some way (although almost all participants were familiar with MCC). This represented just under half of the sample. Participants were recruited from a variety of sources - e.g. social media, LGBT youth groups, LGBT university societies, LGBT support services - but also via advertising on MCC mailing lists. It was not the case that all participants who attended MCC were recruited from MCC. However, recruitment strategies undeniably impacted on the constitution of the sample and thus the nature of the data presented, and so we make no claims regarding how 'representative' this is of the broader population of queer religious youth.

Demographically, those who attended MCC did not differ from those who did not. As in the wider sample, there were a mix of sexual identities amongst those who attended MCC (7 identifying as lesbian, 5 as gay, 2 as queer, 1 as pansexual, 1 as bisexual/fluid and 1 as undefined) and a mix of gender identities (10 identifying as women, 5 as men, 2 as genderqueer and 1 as a trans man). MCC attendees, like the sample as a whole, were either white British or white Other. Class identifications, affiliations, and categorisations were complex and often contradictory, but most participants could be crudely considered middleclass, reflecting comparable research on religion and sexuality in the UK (e.g. Gross and Yip, 2010). And, again as with the broader sample, participants who engaged with MCC came from a range of Christian backgrounds, including Catholic, Pentecostal, Greek Orthodox, Church of Scotland, Evangelical, Methodist and Anglican.

Semi-structured interviews lasting between 1-2 hours were complemented by the use of diaries and mind-mapping, although this article draws exclusively on the interview data (for more detail on methods see Author). Themes explored in the interviews, diaries, and mindmaps included family, education, work, leisure, relationships, identity, future selves - as well as religious belonging, participation and community. Ethical principles of informed consent, confidentiality, and anonymity were adhered to throughout, and all names used are pseudonyms (although see Author for some of the tensions this presented). Data was analysed using qualitative data analysis software, with the research team creating approximately 50 codes which reflected common themes arising across in the interviews, diaries, and mindmaps. For the purposes of this article, the code 'MCC' was subjected to further in-depth analysis, with a number of sub-themes identified within this.

\section{Feeling Included: Metaphors of Home and Family}

Almost all participants invoked the language of 'home' and 'family' when discussing their feelings about MCC. This was often put very straightforwardly, such as when Laura (25, lesbian woman) was asked what MCC meant to her and she answered simply: 'family'. 
Although this was often meant as a metaphorical kind of family, it sometimes translated into real familial-type relationships, as Nicola (21, gay woman) described:

When [MCC congregant] found out I didn't really have a Mum, she went 'Oh I can give you a Mum!'... and one of the ladies was kind of 'I'll just adopt you as my little daughter' and that's really nice... The people are wonderful; I love them, absolutely.

Whilst 'home' and 'family' can have multiple (and contradictory) associations attached to them, in the context of MCC, these were terms which were used to denote affective feelings of safety, security and comfort (Moran and Skeggs, 2004). Sandra (24, lesbian woman) spoke very evocatively of this when she said: 'MCC to me is security and warmth and a shelter from the storm. It's an abode, a home'. For Sandra, MCC was a constant, unconditional and non-judgemental presence: 'it's just there for how and as people need it. It's kind of...it's unconditional really, in ways that most churches aren't'. The succour Sandra found in MCC was shared by numerous participants, and like Sandra, they often commented on the exceptional nature of this space. Rebecca $(22$, bisexual/sexually fluid woman) said the following:

It provides a space that's really secure and there's a lot of safety in that space and no one judges anyone... It's actually quite an odd space because I think people get judged all the time and in that space people kind of don't, and it's very unusual, I think.

There is of course a long historical symbolism of the idea of church-as-family within Christianity (Sharma and Guest, 2013: 17), and recent research indicates that other young people also experience church as a non-judgemental safe space (Finlayson, 2012). However, this familial embrace of the church has been (and often continues to be) limited to certain kinds of bodies. Indeed, some participants had experienced rejection and exclusion from other churches on account of their sexualities. In this sense, MCC provided a literal refuge for 'people who have been rejected from other places' (Sandra) or who have 'felt unwelcome in their own church' (Kate [26, queer woman]). Nicola also spoke about how her religious parents had cut her off upon discovering she was gay, and had not spoken to her since. Her 'actual' family and home had thus come to mean something quite different than the safety, security and acceptance she experienced at MCC. To experience MCC as 'family' and 'home' thus took a particular significance for queer young people when 'home' and 'family' have not always been accessible - either literally, as above, or figuratively, as the 'home' and 'family' continue to be heteronormatively constructed (Wilkinson, 2014). Gorman-Murray et al. (2015: 242) speaks to what is at stake here when he writes: 'home provides ontological security - a safe place that secures a sense of identity and agency'. Indeed, the idea of MCC as home and family was also linked to the idea of participants being able to 'be oneself'. The idea of 'being oneself' -with its implications of an essential modernist subject - is often a target of queer critique (Lovaas et al., 2006) but it was clear from participants' accounts that being able to 'be oneself' was not something to be taken for granted. Despite increasing legal and institutional equality in the UK, the world was still often experienced as a place where queer people couldn't be themselves. For example, Rebecca talked about the happy realisation she had had at her local MCC about how many same-sex couples were holding hands during the service - a happiness that came from the knowledge that 'you wouldn't get 
that' elsewhere. This was echoed by Claire (24, lesbian woman): 'just the fact that we could be there and be a couple and no-one was judging us - the major thing, really'.

Phenomenologically, participants experienced 'ease' in the space of MCC. Ahmed (2006) writes that the space of the world is comprised of lines or furrows which 'orient' and direct us, and which are simultaneously made in the process of being followed. These lines are gendered, racialized, classed and sexualised, and thus are shaped to fit (and shaped by) certain bodies more than others. Being 'in line' is an experience of naturalisation, of familiarity, of 'fit' - so much so that the when we are in line we lose sight of the line, and it becomes 'an expression of who we are' (Ahmed, 2006: 19). Conversely, being 'out of line' is an experience of conspicuousness: drawing on Fanon, Ahmed writes that being black or nonheterosexual means one is unable to immerse oneself in the fabric of the social world in the way that white people and heterosexuals can (Ahmed, 2006:). For Rebecca, Claire and others, to be a same-sex couple holding hands in public was an experience of being out of line. However, within the space of MCC, they were able to experience an ease and easiness normally denied them; Claire's remark 'just the fact that we could be there' indicates this phenomenological feeling of the comfort of being able to 'just be there'.

Participants' attachment to MCC was also largely affective and emotional, rather than intellectual. When asked if they knew about the history of the MCC, participants (who were all attendees of MCC) tended to respond in the negative ('No, not much' - Debbie [30, lesbian and genderqueer]; 'I don't, no' - Anthony [29, gay man]; 'not the MCC as a whole' Gavin [23, gay man]). Similarly, some participants were unsure of the theological/denominational stance of the MCC, such as Jorge (30, gay man): 'I am not sure what MCC is. I know they are Protestant but I haven't got a lot of knowledge'. However, Jorge went on to say that: 'it's important that you go to church because you believe, not around studying or the activity they do'. For Jorge, knowing the history and theological underpinnings of the MCC was of secondary importance to the more affective feelings of faith and belonging that brought him to worship at MCC. A key element of feeling MCC as home, and being at home with MCC, was due to them being of recognition as subjects, as a key factor of liveability (Butler, 2004).

\section{MCC and the Subjectivisation of Religion}

The feelings of belonging that participants found in MCC might be contextualised by understanding MCC as a space of 'subjectivisation' of religion. Heelas and Woodhead (2005:10) describe this as 'the growth of a less regulated situation in which the sacred is experienced in intimate relationships with subjective-lives'. External religious authority structures are loosened as more onus is placed on an individual's personal spiritual path, echoing broader sociological theories of detraditionalisation and individualisation of late modernity (Giddens, 1991; Beck et al., 1994). Empirical research suggests that subjectivisation may be particularly pronounced for LGBT Christians, for whom cultivating a personal experience of and relationship with God has (often out of necessity) become more important than church or the bible in constituting Christian faith (e.g. Yip, 2002). Many of Yip's participants continued to attend church, but subjectivisation was understood as something they developed as a necessary protective mindset for their continued engagement with institutional settings. Participants in our study also drew heavily upon discourses of subjectivisation, but an important element was that MCC was also significantly involved in 
this process. Matthew Wood critiques work on religious subjectivisation for drawing a hard and fast distinction between external authority and self-authority; he is also critical of the tendency to see subjectivisation as always already fully-formed without studying its production in the 'context of people's practices and interactions' (Wood, 2009: 240). In the case of MCC, the subjectivisation that participants displayed was something that was partially created in the liturgical and ritual space and practices of MCC services. For example, Claire describes the ethos of MCC as the following: "we ask that you are sincerely seeking a relationship with God, so basically we ask that you are exploring, we don't ask that you subscribe to a certain dogma'. It is openness and a willingness to 'explore' that become alternative criteria for belonging. Other participants also stressed the centrality of one's own relationship to God. This was often related to the material space in which MCC services were held. This was often in church halls or community centres, since MCC congregations often rent out space from other churches or organisations. As such, these spaces often lacked the ornamentation of traditional worship spaces. Sandra said:

To be in a church hall and to have all of that stripped back; just the simplicity of...well, it was more or less bare walls, there was notice boards but pretty much tables and chairs...because in some ways it made it what it was about, it was just about being there with God.

The stripped back nature of the space in which MCC was held was thus linked to the central and most important goal of 'just being there with God'. Kate also spoke of how in church halls, 'layouts are more flexible and things can be moved around'. This meant that space could be reconfigured to reflect MCC philosophy: Kate spoke about how the altar, for example, could be moved to the centre of the room to symbolize inclusiveness and a lack of hierarchy. By being able to move things around, emphasis shifted from a fixed set of rituals and liturgy, to a flexibility in being able to respond to what was right for that particular service. The flexibility of space offered by venues such as church halls also meant that bodies within that space were more free to move around. Andrea (24, lesbian woman) describes how this was something she particularly appreciated:

I do think that space makes a big difference in how you use it, whether you move about within it, whether you're constrained by that space in terms of having to sit in pews.... we didn't have to be constrained by this space and we could do something different within it. And I think that does make a big difference, it effects how you interact with other people, and how you interact with God.

The ability to reconfigure space meant Andrea felt less constrained physically, and in turn, this helped her to feel less constrained in her relationships with both her peers and with God. It was symbolic of a sense of 'doing something different'. At the same time, movement was also not prescribed; participants talked about experiencing agency in how and when they moved, as compared to traditional church services. As Andrea goes on to say:

They invite you to rise up if you are able, so just for me it suddenly highlighted that...we'd always been demanded to stand up, 'And now you sit down and now you do this'. And it's not just even if you're able, because sometimes some people don't feel 'Okay, its not appropriate for me to stand up for this hymn' so they stay sitting down. That was nice, to give you a bit more ownership of your own time. 
Not only did this approach take into account differing forms of embodiment and mobility, but Andrea discusses how this also afforded congregants a sense of 'ownership' over their practices of worship. They had flexibility in being able to decide what was appropriate for them personally at any particular time. Thus, these accounts show how subjectivisation is encouraged, facilitated and perhaps even produced through these institutional practices, rather than something that only happens in private, on an individual basis. However, Rebecca also hints at some limitations when she says:

It's very open for anyone to worship in whatever way they want, they do say that you can take part in however much of the service you feel comfortable with, but no one doesn't take part in the full service, and so...it becomes sort of a homogenous unit that everyone does the same thing and if you don't then you are sort of noticed.

Thus, it may be the case that subjectivisation can only go so far in the liturgical space; discursively it is encouraged, but in embodied practice, to actually enact agency becomes more difficult.

\section{Feeling Tradition}

The subjectivisation thesis as applied to MCC is also complicated by the fact that several participants who attended MCC also continued to attend churches of their 'own' denomination. Thus, it was not the case that once participants found MCC, all ties with their previous churches and congregations were severed. Kate, who was training for ordination with MCC, spoke of this practice:

They want their tradition and they want their background, so they will go back to the Roman Catholic Church or Anglican Church, but what they have [here] is a space that they can come to either be around other gay Christians or maybe they've just had this time on their journey when they perhaps have a rest.

MCC was conceptualised as a space of peace and healing, but it was not seen as exclusive of attendance at other churches. Indeed, it could even be seen as a waystation on one's journey, rather than a permanent home, as Kate goes on to explain: 'Often we give people a breathing space to find somewhere where they are going to be valued, and if that means that they don't stay, it doesn't matter'. This points to the continuing importance of affective ties to 'tradition' and 'background'. MCC might be conceptualised in terms of home and family, and a place to form a personal relationship with God, but for many participants, the familiarity of worshipping within the context and tradition of their own denominational background had a particular pull. MCC's liturgy is deliberately eclectic ('our service is... a mixture of different traditions and styles because we're aware that we want everyone to recognise an element of what they experience' - Claire) but this eclecticism was sometimes experienced as jarring in itself. Rebecca spoke of her discomfort with mixing different denominational styles, saying: 'Some of it I do find hard to put together...I'm used to either the Catholic or the Anglican service, which has a kind of constant idea'. Other participants who actively identified as 'a bit more traditional' spoke of finding services a bit 'wishy washy' (Gavin), and Debbie admitted that she would like to see 'more enforcement of worship', indicating her desire for less 'subjectivisation'. 
John (21, gay man) who attended MCC regularly, also expressed theological doubts about MCC, invoking a more traditional image of God as an authority figure, rather than a God one can have a personal relationship with:

I would still in the back of my mind have the burning thought of maybe MCC have got it wrong and the Catholic church has got it right.... I sometimes feel bad at the MCC because I go along with, say I do believe in God then if MCC has got it wrong and, for reasons unbeknown to us, God does not favour gay people, then we are sort of celebrating God in His house and all the gays together, and I just feel a bit uncomfortable about it.

Participants who did not attend MCC are also illustrative here. Helen (20, bisexual woman) did not attend MCC, and whilst acknowledging the benefits of an 'inclusive church', ultimately made the decision to remain in her non-inclusive church even though it had displayed undercurrents of homophobia. She said: because 'I'm quite attached to my own church....it meets my needs in terms of sort of prayer and worship, so I'd much rather feel that, be part of that community'. Previously, we have discussed how queer religious youth often spoke positively about their experiences of faith schools (Authors), even when conservative views were expressed regarding non-heterosexualities. We argued that 'religious' is just as much a part of their identity as 'queer', and indeed, for some participants, was more important. Thus, faith schools were also experienced as places of support. Similarly, in discussing queer religious youth's relationship with churches, we should not downplay the importance of religious belief at the expense of centring sexuality. Tradition, background, existing communities and theological beliefs were important for participants. It was for this reason that some chose to stay at their non-inclusive churches, and why many participants who also attended MCC continued to retain links with churches of their denomination. Being able to have a space as a LGBT Christian was important (as we can see in the positive ways participants spoke about MCC) but many found MCC too much of a 'broad church', which could not cater (at least exclusively) to their needs as people of religious faith. Indeed, the language of a church being 'inclusive' or not is, we argue, problematic - inclusivity is defined solely in terms of acceptance/affirmation of non-heterosexuality, but as we have seen, inclusive needs to be stretched beyond this to accommodate other aspects of participants' lives.

\section{Religious-Sexual Exclusion}

Indeed, expanding on the above section, some participants felt that MCC was too gay, in that it had too much of a single issue focus. Tom (20, pansexual trans man) felt there was too much emphasis on the 'gay' as opposed to the 'Christian'. Tom talked about how every MCC service he had attended was about '[sexual] diversity', which frustrated him, as this 'isn't like the only Christian issue ever'. To Tom's mind, this has had the effect of erecting barriers within the Christian community:

I felt that they were quite negative about straight culture or about the church in a whole, and I felt that they sort of felt that they had a battle to win, which I think is relevant and it is sort of important to advocate for LGBT people in religion, but I think that by separating themselves they are sort of making a statement, like, 'We are right and you are wrong'. 
For Tom, MCC has itself become dogmatic in its advocacy of LGBT rights which he doesn't feel is productive in the long run. Tom's identity as a Christian, and his sense of himself as belonging to a wider imagined Christian community, is as equally important to him as his identity as an LGBT person. Rebecca also mused upon how attending MCC might cause her to foreground her sexuality in a way that she wouldn't normally do because of MCC's focus as an LGBT church: 'Within that environment everyone is sort of defined by their sexuality...I wonder whether I kind of perform to that, I kind of make my sexuality part of, a bigger part of me than it actually is'.

Other participants felt that MCC was also too focused on the 'gay stuff' and would like to see 'social justice [issues being discussed] but not just about gay' (Gavin). As an example, Gavin suggested MCC could talk more about climate change, which his previous Church of Scotland denominational church had addressed. Kate, in her role of future MCC pastor, felt that this over-focus on gay/LGBT was deleterious to the long-term growth of the church. In contrast to the context in which MCC was founded, Kate alludes to Western societies being in a kind of 'post-gay' era, no longer defined by identity politics. According to Kate, 'the world has moved on' and so she feels MCC also needs to move beyond proclaiming 'This is MCC, it's the gay Church; this is MCC, it was founded by a gay man and all our priests are gay'.

However, in contrast, some participants felt that MCC wasn't gay enough. John, who expressed theological doubt about MCC, attended MCC largely for social rather than religious elements. He talked about how: 'MCC doesn't give me anything more spiritual than I could get from the church that I've being going to'. He feels that his religious needs can be catered to elsewhere. He is there because MCC is a space for gay Christians, and if the gay element of MCC was downplayed, then he might as well stop going:

Like, the whole thing about MCC is just, to me, I just meet gay Christians, and the gay part is fundamental, it's not just a church where, like any other, and everyone happens to be gay, that part has to be central to me because if I wanted to pray I'd just go to my Catholic church at home and it would have nothing to do with being gay...I would prefer for it to be a little bit more discussed. I understand why they don't because they want to be 'We're just like everyone else. We're here to worship but we happen to be gay' so they don't want to overplay the gay thing because then it just turns into novelty. But, the only reason I'm there is for that.

From John's perspective, MCC is so intent on normalizing the 'gay aspect' that it often slips from view entirely. Whilst Tom, above, sees MCC as segregating itself from the wider Christian community on the basis of difference, John sees MCC as overly keen to assimilate into mainstream Christianity through emphasizing sameness ('we're just like everyone else'). But for John, this misses the point that MCC is a space specifically designed to cater for $L G B T$ people of faith. It is the Christian identity of MCC that is emphasized in Tom's account, while the LGBT identity is emphasized in John's.

MCC's relationship to gay/LGBT was also brought out in discussions of the 'scene'. Many participants talked about how they liked MCC because it was a queer space apart from the 'scene', which they saw as overly-dominated by the night-time economy. Wilcox's (2003) participants also welcomed the fact that MCC was separate from the bar scene, and felt MCC was a reprieve from the noise, late nights, and emphases on youth and beauty found in other 
queer social spaces. However, participants in this study particularly emphasised the sexualised aspect of the queer scene. When asked what MCC meant to him, Jorge said: 'an affirmation that gay people don't have to meet at night in Soho. That we can do something different'. Soho here stands in for a hyper-sexualised gay culture which Jorge feels is limiting and confining. MCC, for Jorge, is about recognising the multi-dimensionality of queer lives, beyond the stereotype of gay culture as hedonistic, sex-obsessed, and promiscuous. John, who as we have seen valued MCC because it was a gay church, nevertheless spoke of how he enjoyed MCC as a different kind of space that those that usually make up the scene:

I try to hunt out spaces that are queer spaces that are non-sexualised and not based on the same morality as what the gay scene is and places like MCC I suppose provide that because it's a queer space and it's completely non-sexualised.

Frustration with the scene in this regard is not unique to religious queer people. For example, one participant in expressed dismay that the scene is 'all based around the night' (See Author). Whilst (somewhat ironically) MCC meetings were sometimes held in scene spaces with sexualised connotations ('one of the bible studies we do with MCC is usually in a pub in Soho' - Kate), there was still a sense of MCC as an exceptional space, a space apart.

However, some participants disagreed. For them, MCC was still too sexualised and 'scenelike'. Tom said the following:

I also think that there can be quite a lot of dating culture at MCC, as in, a lot of people go there to find a Christian LGBT partner, which can be a bit weird. Like, they've got quite a lot of people coming on to me, when I first went there, which just seemed strange, for a church.

Rather than the non-sexualised space related by John, Tom has experienced MCC as an extension of scene space in which sexual and romantic partners are being actively sought, and he can still be 'targeted' in this way, which causes him discomfort and unease. For Tom, there is an incongruence between church, and 'dating culture'. Whilst evaluations regarding how sexualised or scene-like the MCC was differed, it was clear however that the participants quoted above were all searching for a space that was 'apart', by which they meant nonsexualised. However, perhaps significantly, participants who expressed desire for a nonsexualised space were all men; this was not something that came up in women's accounts, perhaps indicating a sense that queer women may have experienced the scene as less aggressively sexual, as compared to gay men (Author). Geographies of sexuality have tended to focus on, and sought challenge, the notion of LGBT spaces as separate sites of activity and connection, facilitated and contained in particular urban locales and imaginaries, this is stretched here in considering religion as part of sexual inclusion-exclusion.

\section{Conclusion}

This article makes initial inroads in exploring how queer religious youth in the UK engage with the MCC. Amidst more tragic narratives of queer youth, we have tried to show how MCC provides an important source of wellbeing in the lives of many participants. This is evident through participants' deployment of language of home and family, and the phenomenological 'fit' reported by many. We also suggested that MCC's ethos and liturgical practices could be characterised in terms of the 'subjectivisation' of religion, which allowed 
participants 'ownership' over their own worship. Here we challenge overly-individualised accounts of subjectivisation, suggesting how subjectivisation were created in social and relational contexts. However, the paper also showed how subjectivisation was not in opposition to tradition, as many participants continued to attend churches from their own and their family's denominations, even if they were 'non-inclusive', citing the importance of tradition and background, and calling for a stretching of what we include when we talk about inclusivity. This lead to a discussion of alternate views regarding the focus MCC should have: i.e. if it should continue to be primarily a gay church, or a gay church, with participants expressing different views on sameness vis a vis difference. Participants differed too in whether or not they saw MCC as part of the queer scene, but there was a commonality in that male participants desired a non-sexualised space, away from the relentless hypersexualisation of queer (or gay male) scene spaces. Religion and sexuality constitute flashpoints in current Western socio-political discourse, with religion and non-heterosexualities frequently characterised as mutually exclusive, but there is much to learn in considering the intersection, rather than inevitable collision, in producing 'liveable lives' for queer religious youth.

\section{Bibliography}

Ahmed S (2006) Queer Phenomenology: Orientations, Objects, Others. Durham: Duke University Press.

Althaus-Reid M (2000) Indecent Theology. Oxon: Routledge.

Aune, K. (2015), 'Feminist Spirituality as Lived Religion: How UK Feminists Forge Religiospiritual Lives' Gender and Society, 29(1): 122-145.

Aune, K. and Stevenson, J. (2017), Religion and Higher Education in Europe and North America. Research into Higher Education (Co-published with the Society for Research into Higher Education), 1st edn, Routledge, London.

Beck, U., Giddens, A. and Lash, S. (1994) Reflexive Modernization. Politics, Tradition and Aesthetics in the Modern Social Order. Cambridge : Polity

Butler, J. (2004) Precarious Life: The Powers of Mourning and Violence. London New York: Verso.

Callaghan TD (2016) Young, queer, and Catholic: Youth resistance to homophobia in Catholic schools. Journal of LGBT Youth 13(3): 270-287.

Collins-Mayo S and Dandelion P (2010) Religion and Youth. Aldershot: Ashgate.

Cover R (2012) Queer Youth Suicide, Culture and Identity. London: Routledge.

Davie, G. and Vincent, J. (1998) 'Progress Report Religion and old age' Ageing and Society, 18: $101-110$

Enroth RM and Jamison GE (1974) The gay Church: An on-scene report. Grand Rapids, MI: William B. Eerdmans. 
Ganzevoort R et al. (2011) Growing up gay and religious: conflict, dialogue, and religious identity strategies. Mental Health, Religion and Culture 14(3): 209-222.

Giddens, Anthony (1991) Modernity and Self-Identity. Self and Society in the Late Modern Age. Cambridge: Polity.

Gorman-Murray A, McKinnon S and Dominey-Howes D (2015) Queer domicide. The Journal of Architecture, Design and Domestic Space 11(2): 237-261.

Gross M and Yip AKT (2010) Living spirituality and sexuality: a comparison of lesbian, gay and bisexual Christians in France and Britain. Social Compass 57(1): 40-59.

Heelas P and Woodhead L (2005) The Spiritual Revolution: Why Religion is Giving Way to Spirituality. Oxford: Blackwell.

Howe, C (2007) Sexual Borderlands: Lesbian and Gay Migration, Human Rights, and the Metropolitan Community Church. Sexuality Research \& Social Policy 4(2): 88-106

Johnston LB and Jenkins D (2004) A Gay and Lesbian Congregation Seeks Social Justice for Other Marginalized Communities. Journal of Gay \& Lesbian Social Services 16(3-4): 193206.

Kane MD (2013) LGBT Religious Activism: Predicting State Variations in the Number of Metropolitan Community Churches, 1974-2000. Sociological Forum 28: 135-158.

Loseke D and Cavendish J (2001) Producing Institutional Selves: Rhetorically Constructing the Dignity of Sexually Marginalized Catholics. Social Psychology Quarterly 64(4): 347-362.

Lovaas KE, Elia JP and Yep GA (2006) Shifting Ground(s): Surveying the Contested Terrain of LGBT Studies and Queer Theory. Journal of Homosexuality 52(1-2): 1-18.

Lukenbill W (1998) Observations on the Corporate Culture of a Gay and Lesbian Congregation. Journal for the Scientific Study of Religion 37(3): 440-452.

Madge $\mathrm{N}$ et al. (2014) Youth On Religion: The development, negotiation and impact of faith and non-faith identity. London: Routledge.

MCC (2012) Global Presence of Metropolitan Community Churches. Available at: http://mccchurch.org/files/2009/08/MCC-GLOBAL-PRESENCE-as-of-June-23-2012.pdf (accessed 9th September 2017).

MCC (2013) History of MCC. Available at: http://mccchurch.org/overview/history-of-mcc/ (accessed $9^{\text {th }}$ September 2017).

MCC (2015) A Companion Guide to the MCC Statement of Faith. Available at: http://mccchurch.org/files/2016/08/Companion-Guide-to-the-2016-MCC-Statement-of-Faith1.pdf (accessed 9th September 2017).

MCC (2016) The Bible and Homosexuality. Available at: http://mccchurch.org/files/2016/08/BibleandHomosexuality.pdf (accessed 9th September 2017).

McDermott, E. and Roen, K. (2016), Queer Youth, Suicide and Self Harm: Troubled Subjects, Troubling Norms. Houndsmills: Palgrave. 
McQueeney K (2009) 'We are God's Children, Y'All:' Race, Gender, and Sexuality in Lesbian- and Gay-Affirming Congregations. Social Problems 56(1): 151-173.

Monk D (2011) Challenging homophobic bullying in schools: The politics of progress. International Journal of Law in Context 7(2): 181-207.

Moran L and Skeggs B (2004) Sexuality and the Politics of Violence and Safety. London: Routledge.

O'Brien J (2014) Outing religion in LGBT Studies. In Taylor Y and Snowdon R (eds.) Queering Religion, Religious Queers. New York and London: Routledge

ONS (2014) Large increase in 20 to 34-year-olds living with parents since 1996. Office for

National Statistics Press Release. Available at: http://www.ons.gov.uk/ons/rel/familydemography/young-adults-living-with-parents/2013/sty-young-adults.html (accessed 12th September 2017).

Page S and Yip AKT (2016) Gender equality and religion: A multi-faith exploration of young adults' narratives. European Journal of Women's Studies. Online First, 1-17

Paris JW and Anderson RE (2001) Faith-based Queer Space in Washington, DC: The Metropolitan Community Church-DC and Mount Vernon Square. Gender, Place \& Culture 8(2): 149-168.

Radojcic N (2016) Building a Dignified Identity: An Ethnographic Case Study of LGBT Catholics. Journal of Homosexuality 63(10): 1297-1313.

Rasmussen ML (2006) Becoming Subjects: Sexualities and Secondary Schooling. London: Routledge.

Rodriguez E (2009) At the Intersection of Church and Gay: A Review of the Psychological Research on Gay and Lesbian Christians. Journal of Homosexuality 57(1): 5-38.

Rodriguez E and Ouellette S (2000) Gay and Lesbian Christians: Homosexual and Religious Identity Integration in the Members and Participants of a Gay-Positive Church. Journal for the Scientific Study of Religion 39(3): 333-347.

Sharma S and Guest M (2013) Navigating religion between university and home: Christian students' experiences at English universities. Social \& Cultural Geography, 14(1): 59-79.

Shipley H (2014) Religious and sexual orientation intersections in education and media: A Canadian perspective. Sexualities 17(5-6): 512-528.

Shokeid M (1995) A Gay Synagogue in New York. NY: Columbia University Press.

Sumerau JE (2012a) 'That's what a man is supposed to do': Compensatory Manhood Acts in an LGBT Christian Church. Gender and Society 26(3): 461-487.

Sumerau, JE (2012b) 'Mobilizing Race, Class, and Gender Discourses in a Metropolitan Community Church' Race, Gender and Class (2012), Vol.19(3/4) pp. 93-112 
Sumerau JE (2017) 'Some of Us Are Good, God-Fearing Folks': Justifying Religious Participation in an LGBT Christian Church. Journal of Contemporary Ethnography 46(1): 329.

Sumerau JE, Padavic I and Schrock DP (2015) 'Little Girls Unwilling to Do What's Best for Them': Resurrecting Patriarchy in an LGBT Christian Church. Journal of Contemporary Ethnography 44(3): 306-334.

Warner RS (1995) The metropolitan community churches and the gay agenda: Power of Pentecostalism and essentialism. In: Bromley DG et al. (eds) Religion and the social order: Sex, lies, and sanctity: Religion and deviance in contemporary North America. Greenwich, CT: JAI, pp 81-108.

Westwood S (2017) Religion, sexuality, and (in)equality in the lives of older lesbian, gay, and bisexual people in the United Kingdom. Journal of Religion, Spirituality \& Aging 29(1): 47-61.

White H (2008). Proclaiming Liberation: The Historical Roots of LGBT Religious Organizing, 1946-1976. Nova Religio: The Journal of Alternative and Emergent Religions, 11(4): 102-11.

Wilcox MM (2003) Coming Out in Christianity: Religion, Identity and Community. Bloomington, IN: Indiana University Press.

Wilkinson E (2014) Single people's geographies of home: intimacy and friendship beyond the 'family'. Environment and Planning A, 46: 2452-2468.

Wood M (2009) The Nonformative Elements of Religious Life: Questioning the "Sociology of Spirituality” Paradigm. Social Compass, 56(2): 237-248.

Yip AKT (2002) The Persistence of Faith among Nonheterosexual Christians. Journal for the Scientific Study of Religion, 41(2): 199-212. 